\title{
Applying the Unified Theory of Acceptance and Use of Technology (UTAUT) in Investigating Online Impulsive Buying Behavior of Vietnamese Consumers
}

\author{
Ha Thu Luong (Corresponding author) \\ School of Advanced Education Programs, National Economics University, Hanoi, Vietnam \\ 207 Giai Phong Street, Hai Ba Trung District, Hanoi 100000, Vietnam \\ Tel: (+84) $903001888 \quad$ Email: haluongthu@neu.edu.vn \\ Trang Thu Nguyen \\ School of Advanced Education Programs, National Economics University, Hanoi, Vietnam \\ Ha Dinh Ward, Thanh Xuan Distrct, Hanoi 100000, Vietnam \\ Tel: (+84) 919782804 ～Email: tranggg.ng2109@gmail.com \\ Hang Minh Pham \\ School of Advanced Education Programs, National Economics University, Hanoi, Vietnam \\ Khuong Mai Ward, Thanh Xuan District, Ha Noi 100000, Viet Nam \\ Tel: (+84) 393732210 Email: hangmp0112@gmail.com
}

\begin{abstract}
Based on The Theory of Adoption and Use of Technology (UTAUT) (Venkatesh et al., 2003), this study builds a research model regarding the Factors affecting Vietnamese consumers' online impulsive buying behavior. The multiple regression results reveal that Performance Expectancy, Effort Expectancy, Social Influence, and Online Buying Intention play a crucial role in amplifying the development of online impulsive buying behavior in Vietnam.
\end{abstract}

Keywords: buying behavior, online buying, impulsive buying behavior, compulsive buying behavior, UTAUT, Vietnam

DOI: $10.7176 / \mathrm{EJBM} / 13-6-19$

Publication date:March $31^{\text {st }} 2021$

\section{Introduction}

In recent years, Vietnam has witnessed the continuously escalating trend of online shopping and the unstoppably growing number of its citizens accessing and using online shopping channels. A survey by GlobalData revealed that, in 2020, sales of e-commerce platforms in Vietnam increased by $30.3 \%$, reaching 13.1 billion USD. Before online buying appeared, impulsive buying behavior had been studied in physical stores (Rook \& Fisher, 1995). However, compared to the offline environment, the online environment has been said to be more favorable for impulsive shopping ( $\mathrm{Liu}, \mathrm{Li} \& \mathrm{Hu}, 2013$ ). Moreover, the rapid growth of e-commerce and advances in information technology (IT) has aroused the worth of buying behaviors in the online context (Lin \& Lo, 2016) and made impulsive buying behavior more popular than ever (Chan et al., 2017). The benefits brought about by these impressive technological developments are helping people around the world in general, and Vietnamese citizens in particular, as they can shop more quickly and easily without having to pay too much thought into their actions. In 2020, impulsive buying behavior had presented a significant influence on the trend of buying online, then evidently exhibited its footprint on the buyers, the sellers, and the suppliers offering the electronic means that help to boost and further validate the process of online purchasing and consumption.

Therefore, investigating and examining the factors which are related to online buying behavior, namely impulsive buying, will provide a basis for in-depth reference and analysis to help develop appropriate policies to boost the economy both inside and outside of Vietnam as well as enhanced the protection for the country's consumers 


\section{Theoretical background \& Literature review}

\subsection{Theoretical background}

\subsubsection{Unified Theory of Acceptance and Use of Technology}

The Unified Theory of Acceptance and Use of Technology (UTAUT) has been developed on the basis of eight well-established theories and models to assess the success possibilities of new technology introductions (Venkatesh et al., 2003). Empirical studies show that this model's interpretability to consumer behavior has reached $70 \%$, which is more effective than all previous models (Venkatesh et al., 2003; Alalwan et al., 2014). According to the UTAUT model, behavioral intention and ultimately usage behavior are affected by "Performance Expectancy" (PE), "Effort Expectancy" (EE), "Social Influences" (SI), and "Facilitating Conditions" (FC). Regarding the relationship between these four constructs, Venkatesh et al. (2003) exert that while performance expectancy, effort expectancy, and social influences impact the behavioral intention to use technology, the facilitating conditions are empirically identified as the direct determinant of actual usage behavior.

Suppose the presence of each of the four constructs is examined in a "real world" environment. In that case, it will help evaluate an individual's intentions to use a particular system, thus allowing researchers to identify factors that are decisive for acceptance in any context (Williams, Rana \& Dwivedi, 2015). Examples of UTAUT's application in consumer contexts including the technologies adoption by users: Mobile banking (Zhou, Lu, \& Wang, 2010); Internet banking (Abushanab \& Pearson, 2007; Im, Hong, \& Kang, 2011; Riffai, Grantb, \& Edgarc, 2012); Mobile phone technologies (Park, Yang, \& Lehto, 2007; Wang \& Wang, 2010; Zhou, 2011); E-recruiting (Laumer, Eckhardt, \& Trunk, 2010) and E-government (Hung, Wang, \& Chou, 2007; Sapio et al., 2010).

Contrary to the traditional method of buying goods at a store, buying goods online is considered a form of accepting and using technology to make purchases. Therefore, UTAUT has been applied by the authors to determine the factors related to online buying behaviors in Vietnam.

\subsubsection{Online buying intention}

Intention is a driving force that can affect the formation of a certain desired behavior and can be used as an indicator to see how much desire and effort one has to execute that behavior (Ajzen, 1991). Therefore, in the sense of this article, purchase intention is described as an individual's willingness to buy an item (Tirtiroglu \& Elbeck, 2008). Furthermore, based on the argument put forward by Zwass (1998), online buying intention can be classified as a consumer's intention to establish online relationships and bargains with retailers on their websites. Similarly, Pavlou (2003) asserts that online shopping is when a buyer is willing and eager to partake in an online transaction. According to the author, online transactions consist of three stages, which are information retrieval, information transfer, and product purchase.

\subsubsection{Online impulsive buying behavior}

Impulse buying behavior is considered an unplanned, decide-on-the-spot purchase based on buyers', often positive, emotions (Piron, 1991; Rook, 1997). Its characterizations are subjective bias, the rapid decision-making process in favor of immediate possession, and diminished regard for future consequences (Rook and Hoch, 1985; Rook 1987). In support of the fact that $40 \%$ of consumers' online expenditures result from impulsive purchases in the present era, $\mathrm{Liu}, \mathrm{Li}$, and $\mathrm{Hu}(2013)$ advocated that the online shopping environment has been more favorable and responsive for impulsive consumption than its offline equivalent. This transformation happens because, nowadays, consumers can enjoy a large number of utilitarian conveniences thanks to rapid developments in ICT, the sharp growth of online shopping websites, and advanced innovations of online payment methods. Moreover, according to Jones et al. (2003), consumers often have a natural tendency towards buying immediately and unintentionally in an online setting, as their intentions might be stimulated by the intricacy or the simplicity of the website (Wu, Chen, \& Chiu, 2016). As a result, their propensity toward enjoyment of shopping than their actual need will likely be increased (Beatty \& Ferrell, 1998). Subsequently, the fact that such unreflective and unintended purchases can account for a noteworthy proportion of consumer purchases has captured constant attention from academicians and practitioners worldwide (Bellini, Cardinali, \& Grandi, 2017; Flight, Rountree, \& Beatty, 2012).

\subsection{Literature review}

The topic of online shopping behavior is no longer new in studies. Overall, among extant studies, the research applies the UTAUT model of Escobar-Rodríguez and Carvajal-Trujillo (2014) to study the key factors influencing the customers' intention and actual behaviors of adopting airlines' airlines to book flights for affordable prices, is quite prominent because it provided similar results with Venkatesh et al. (2003). Their findings suggest that all four factors are major drivers leading to online ticket-buying intention and actual behavior. The predictors of intention, in order of importance, are Performance Expectancy, Effort Expectancy, and Social Influence. As for the predictors of actual online flight buying behavior, the Purchase Intention has proven to bear the greatest and most 
direct influence, followed by the Facilitating Conditions.

Impressed by its rapid development, Zhang and Yang (2019) took the Pinduoduo e-commerce platform as an example to study Chinese consumer buying behavior based on the UTAUT model integrated with three new variables. Regarding the relationship of 7 independent structures, while Performance Expectancy, Effort Expectancy, and Social Influence, Perceived Cost, Perceived Value and Perceived Risk are hypothesized to carry positive effect on Consumption Intention; Facilitating Conditions, and Consumption Intention are said to have a significant impact on the consumers' online Consumption Behavior. Based on the regression results, all four original UTAUT constructs proved to be the direct determinants to explain the online buying intention and corresponding behavior on the e-commerce platform Pinduoduo - which provides similar results with Venkatesh (2003). However, only the relationship between Perceived Value and Consumption Intention is significant among the three variables that are newly integrated.

As for Vietnamese customers related research, based on the argument of Jin et al. (2014): "Most of the studies focus on online purchase intention rather than online shopping behavior that link to the final stage of purchases", Le (2016) has proposed the UTAUT research model that directly studies the factors that affect online shopping behavior on smartphones of consumers in Ho Chi Minh city. The author applies the original UTAUT model with the addition of 4 new variables. A total of 8 independent variables, including Performance Expectancy, Effort Expectancy, Social Influences, Facilitating Conditions, Hedonic Motivation, Trust, Perceived Risk of Product/ Services and Perceived risks of online transactions - are expected to positively explain consumers' online shopping behavior in Ho Chi Minh, except the risk-related variables. Finally, the results of multiple regression analysis found six factors that significantly impact online shopping behavior. In particular, the variable Performance Expectancy has the most substantial impact on online shopping behavior on smartphones, followed by Facilitating Conditions, Social Influences, Effort Expectancy, Trust and Perceived Risk of Product. While Perceived Risk of Product has a negligible impact on online shopping behavior (standard beta equals -0.15), the author still believes it is indeed a factor to be recognized because of its special circumstances - the negative impact on the online shopping behavior of consumers.

Recently, the prominent study by Nguyen et al. (2019), based on the UTAUT model, has proposed an analytical framework using nine explanatory factors to examine customer intentions and especially online shopping behavior through e-commerce websites in Vietnam. Nine independent variables, including Performance Expectancy, Effort Expectancy, Social Influences, Facilitating Conditions, Hedonic Motivation, Price Value, Habits, Trust, and The "Long Tail" Effect, are believed by the authors to be positively correlated with Intention to buy online; while Online Buying Intention is said to have a significant effect on the actual Online Buying Behavior of Vietnamese consumers. Then, based on multiple regression analysis, the research team found that these nine factors are the main drivers of Online Buying Intention, with the following order of impact: Performance Expectancy, Effort Expectancy, Hedonic Motivation Facilitating Conditions, Social Influences, Price Value, Habits, The "Long Tail" Effect and finally Trust. Simultaneously, with a significantly positive impact, Online Buying Intention is considered an important predictor in explaining Vietnamese consumers' online buying behavior.

Nevertheless, very few studies have set out to examine the influencing factors of online impulsive buying behavior by adapting the UTAUT model. To the authors' knowledge, one of which is the study of Kang \& Ahn (2011), which investigates the phenomenon of increasing impulse purchasing in the digital age and its problemsolving by focusing on the impact of 2 variables: Performance Expectancy and Effort Expectancy. According to the authors, in the case of Social Influence, the variable is not as an essential part of the current consumer situation as it was before, whereas it was appropriate to exclude the application of Facilitating Conditions to the consumer situation; thus, it is closer to the organizational system in terms of context. Finally, results suggest that the greater the acceptance of digital technology for purchasing in terms of Performance Expectancy in the UTAUT model, the more buyers will make purchases impulsively. And the greater the adoption of new technologies to problemsolving action after the act of impulsive buying in the aspect of Effort Expectancy, the fewer times they will experience the feeling of remorse in the long run.

Although the extant studies of online impulsive buying behavior are inclined to other models such as TPB or SOR, to study online buying behavior, one technology adoption and behavior model (such as UTAUT) should be considered because it can examine the potential influencing factors in this specific and selective context. To illustrate, consumers' impulsive purchasing is found to be highly impacted by environmental characteristics like website quality (in this case, Performance Expectancy and Effort Expectancy) (Wells et al., 2011). Furthermore, the variable Social Influence can hold a significant meaning in Vietnam, where a large number of consumers buy things according to the surrounding trends because they feel pressure to be recognized and want to enhance their 
social image. Consequently, they indulge in a buying behavior that aligns them with their reference groups, not because of the product's real use. This, in turn, made them more impulsively driven to purchase and consume (Halepete, Littrell \& Park, 2009). Regarding the fourth construct Facilitating Conditions, for example, technological advances and especially increased credit card availability - a convenient and relatively painless way to spend, have made online shopping more manageable and can eliminate the immediate need for cash to buy something. As a result, consumers are prone to overspending (Schor, 1998) and are more likely to accelerate the development of their impulsive buying behavior (Roberts \& Jones, 2001).

To conclude, Venkatesh et al. (2003) suggested that UTAUT should be put to the test in the context of different technologies (particularly e-commerce applications) as the authors are persuaded that such results would offer substantial value in the enhancement of the model's overall generalizability as well as extend their existing work to explain more variance in users' behavior. Bearing that in mind, with the four high-explanatory constructs justified above, this paper decides to apply the UTAUT model to investigate the online impulsive buying behavior of Vietnamese consumers.

\section{Research model and Hypotheses}

Based on the theoretical basis of the UTAUT model, the authors built the final research model with four independent and three dependent variables. In which, four variables Performance Expectancy (PE), Effort Expectancy (EE), Social Influence (SI), Facilitating Condition (FC), are expected to influence Online Buying Intention (IN), while IN is anticipated to affect the Online Impulsive Buying Behavior (IB) (Figure 1).

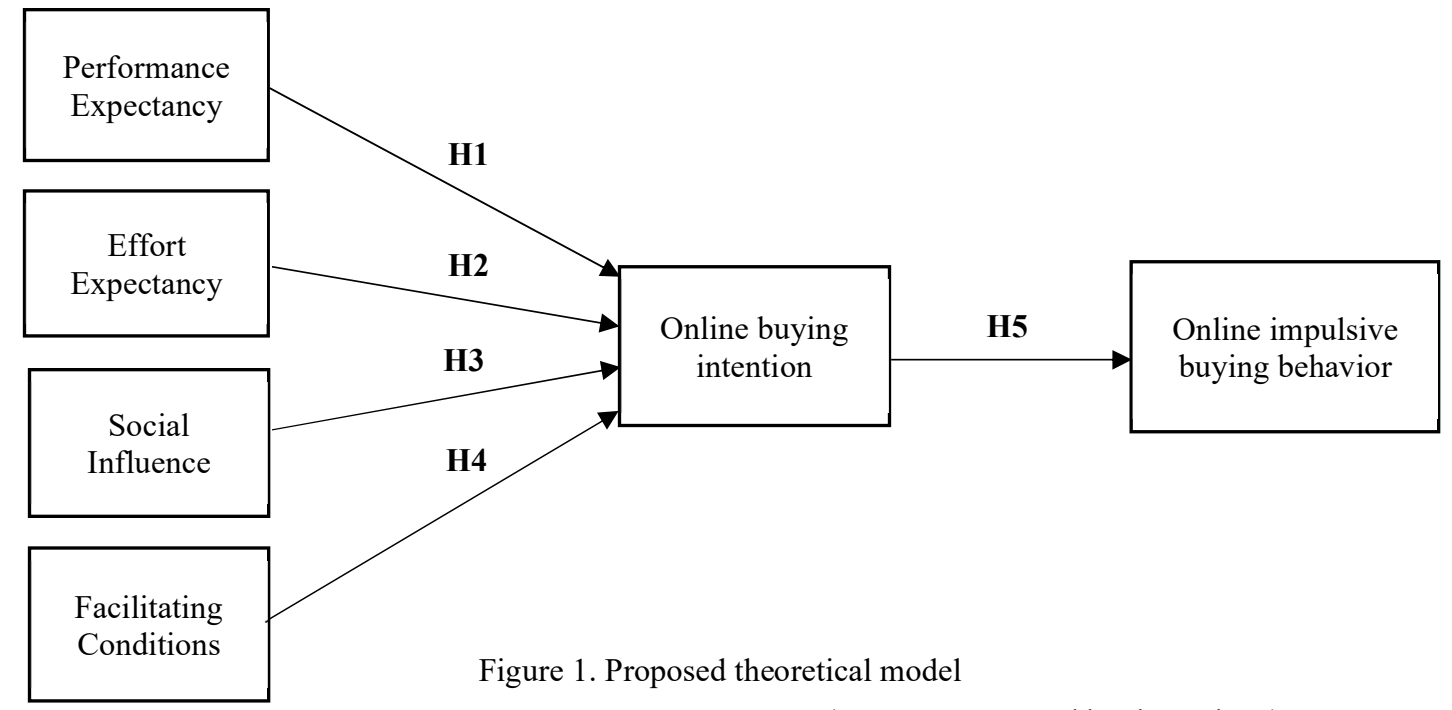

(Source: Suggested by the authors)

\subsection{Performance Expectancy (PE)}

According to Venkatesh et al. (2003), PE is related to how useful people find a new technology in terms of productivity and stime-saving. If the costs are lower than the benefits, the technology's usefulness will be greater, and the intention to use it will be positive. Many studies have experimentally examined and confirmed this proposal (Alwahaishi \& Snásel, 2013; Brown et al., 2010; Sin Tan et al., 2013). A similar result is expected in online shopping. Inheriting the research results of previous studies, the authors propose a hypothesis:

\section{H1: "Performance Expectancy" has a positive impact on online buying intention}

\subsection{Effort Expectancy (EE)}

Effort Expectancy is an effortless personal measure of how technology is used. The behavioral effort required to learn and use an IT component has been proved to directly affect purchase intention, especially during the technology discovery phase (Venkatesh \& Davis, 2000; Rook \& Gadner, 1993). According to Hansen (2006), customers' main reason for choosing an online shopping channel is the minimized physical and mental effort required to complete a shopping mission from other alternative channels. From there, the group made a hypothesis: 


\section{H2: "Effort Expectancy" has a positive impact on online buying intention}

\subsection{Social Influence (SI)}

Social influence is the degree to which an individual perceives that the significant others believe he or she should use the new system. Since online shopping is a voluntary decision, this variable is expected by the research group to directly affect intention due to its internalization, which is caused by users' personal desire to maintain a favorable image and develop consistent beliefs views with their reference groups by using the technology. The same result was documented by Celik (2016). Accordingly, a hypothesis was made:

\section{H3: "Social Influence" has a positive on online buying intentions}

\subsection{Facilitating Condition (FC)}

Facilitating Condition is the degree to which an individual believes there is always outside assistance when using new technology. This factor is valued because it assesses the adequacy of users' knowledge and support from technology publishers. In particular, online shopping also possesses similar requirements for the presence of knowledge, resources, and support to empower customers to overcome restrictions such as lack of tactile shopping experience and direct personal contact with salespeople. Instead, they have to interact with online payment interfaces as well as to track online shipments (Song \& Zahedi, 2005). Through the above conclusions, the authors hypothesized:

\section{H4: "Facilitating Conditions" has a positive on online buying intentions}

\subsection{Online Buying Intention (IN)}

Purchase intent represents a shift between social and personal-related variables and personal use of information technology in UTAUT (Venkatesh et al., 2003). Purchase intent is the closest determinant of users' technology usage in previous UTAUT studies conducted in different environments, including as diverse technologies as mobile banking (Yu, 2012), online social support (Lin \& Anol, 2008), collaborative technology (Brown et al., 2010), Facebook (Lallmahomed et al., 2013) and mobile internet (Venkatesh et al., 2012). There is also evidence that stronger customer intent leads to higher determination to shop online. In terms of online shopping impulsively, with IT development, consumers can order and buy goods from websites and 24/24 available retail services. Therefore, consumers' likelihood of buying impulsively is expected to increase thanks to online shopping convenience (Rook \& Fisher, 1995; Koufaris, 2002; Dittman et al., 2007). From the above research results, the authors propose a hypothesis:

\section{H5: “Online Buying Intention" has a positive impact on online impulsive buying behavior}

\section{Research methodology}

\subsection{Data collection and sample characteristics}

Table 1: Sample characteristics

\begin{tabular}{lll}
\hline & Number & Percentage \\
\hline Gender & & 34.6 \\
\hline Male & 201 & 65.4 \\
\hline Female & 382 & \\
\hline Age (years old) & & 3.1 \\
15 to 18 & 18 & 11.0 \\
18 to 22 & 64 & 37.4 \\
22 to 30 & 218 & 34.5 \\
30 to 40 & 201 & 7.4 \\
Above 40 & 43 & 6.7 \\
\hline
\end{tabular}

(Source: Research result)

The population of the study comprises all Vietnamese citizens who are able to use online shopping applications. This research's required information was not available in secondary data, so we conducted a survey to gather the primary data. The questionnaire, which had been developed using constructs and items from literature and hypotheses, included two segments: the first part contained queries about demographic information, and the second one was made up of questions to evaluate the impact of four mentioned factors on users' intention as well as the influence of the intention on behaviors. Due to the limited resources, we only approach online shoppers 
whose permanent addresses are located in Hanoi.

At the end of the collection period, there are a total of 652 responses, of which 104 of them were collected offline, and the other 548 were obtained through online surveys. Then we re-examined all responses to remove anything invalid, illogical, or lack essential information. Of the 652 answers we collected, 583 of those had passed our validation tests and could be used for the later analysis stages.

\subsection{Measures}

The survey questionnaire to test the theoretical hypotheses was based on theory and additional items from literature. Measurement items for performance expectancy (PE), effort expectancy (EE), social influence (SI), facilitating conditions (FC) and behavioral intention (BI) were adopted from Venkatesh et al. (2003); Yang (2010), and Celik (2016). All the measurement items were formulated as Likert 5-point scales, ranging from 1 (strongly disagree) to 5 (strongly agree). There also were modifications in those items in order to fit the context of our survey.

\subsection{Estimation approach}

In this study, multiple regression analysis was chosen to estimate the relationships assumed in the theoretical model. First of all, we tested the scales' reliability and validity using Cronbach's Exploratory Factor Analysis (EFA). Then, we estimated the correlation coefficients between the variables to determine whether there were linear relationships between them. Finally, we used the OLS method to assess the effects of explanatory variables on explained variables. All of those stages were processed on SPSS 22.

\section{Results}

\subsection{Reliability and validity of the scales}

Table 2: Reliability analysis

\begin{tabular}{lllll}
\hline \multirow{2}{*}{ Factor } & \multicolumn{2}{l}{ Number of observed items } & Cronbach's Alpha & $\begin{array}{l}\text { Factor loadings } \\
\text { minimum }\end{array}$ \\
\cline { 2 - 3 } & Before & After & & 0.848 \\
\hline Performance expectancy & 4 & 4 & 0.895 & 0.713 \\
\hline Effort expectancy & 5 & 5 & 0.806 & 0.484 \\
\hline Social influence & 5 & 5 & 0.739 & 0.344 \\
\hline Facilitating conditions & 4 & 4 & 0.897 & 0.568 \\
\hline Behavior intention & 5 & 5 & 0.870 & 0.525 \\
\hline Impulsive buying & 6 & 6 & & (Source: Research result)
\end{tabular}

In this study, the research group carried out the reliability test for proposed scales using Cronbach's Cronbach's coefficients. The coefficients' values ranged from 0.79 to 0.897 , and the Corrected Item - Total Correlation of every item was above 0.3 , which implied that all the variables were sufficiently reliable, according to Nunnally (1974).

\subsubsection{The validity of independent variables}

All 35 items were subjected to exploratory factor analysis (EFA) using principal components analysis (PCA) and the Varimax rotation method for gauging each variable's validity. Criteria of the factor analysis method are: the KMO index must be greater than 0.5 (Field, 2013), and Barlett's test has a significance of p-value less than 0.05 to show that the data used for factor analysis is appropriate and the variables are correlated with each other. Furthermore, items that loaded weakly on factors, loaded on more than one, or loaded on multiple factors should be dropped.

Table 3: KMO and Bartlett's Test for independent variables

\begin{tabular}{lll}
\hline \multicolumn{3}{l}{ Kaiser-Meyer-Olkin Measure of Sampling Adequacy. .915 } \\
\hline Bartlett's Test of Sphericity & Approx. Chi-Square & 5215.713 \\
\hline & df & 153 \\
\hline Sig. & .000 \\
\hline
\end{tabular}

(Source: Research result) 
Factor analysis results showed that the KMO value is $0.915>0.5$, indicating that the data used for factor analysis is appropriate. Barlett's test result is 5215.713 with a p-value $=0.000$. Thus, the hypothesis H0 (the observed variables are not correlated with each other in the population) was rejected, and all the scales satisfied the factor analysis conditions at a 5\% significance level.

All items loaded on four factors and rotation sums of squared loadings value showed that those factors explained a total of $65.081 \%$ of the variance. As no items were eliminated, four key factors, which had been identified through EFA, were equivalent to the potential variables in the hypothetical model, which are: Performance expectancy (PE), Effort expectancy (EE), Social influence (SI), and Facilitating conditions (FC).

\subsubsection{The validity of dependent variables}

We also conducted exploratory factor analysis (EFA) using principal components analysis (PCA) and the Varimax rotation method for assessing the validity of the explained variables. The criteria applied were the same as those mentioned above.

Table 4: KMO and Bartlett's Test for dependent variables

\begin{tabular}{lll}
\hline \multicolumn{3}{l}{ Kaiser-Meyer-Olkin Measure of Sampling Adequacy. 897} \\
\hline Bartlett's Test of Sphericity & Approx. Chi-Square & 3605.353 \\
\hline & df & 55 \\
\hline Sig. & .000 \\
\hline
\end{tabular}

(Source: Research result)

Factor analysis results showed that the KMO value is $0.897>0.5$, implied that the data used for factor analysis is appropriate. Barlett's test result is 3605.353 with a p-value $=0.000$, indicated the explained variables are correlated and those satisfied the factor analysis conditions at a 5\% significance level. The items loaded on three factors, and they explained $66.499 \%$ of data variation. As there is no eliminated scale during factor analysis, two dependent variables are IN (6 items) and IB (6 items).

\subsection{Correlation analysis}

From Pearson's correlation analysis, there were linear and positive correlations between four independent variables and users' intention. Linear relationships between intention and intensive buying behaviors were also positive. All of those correlations are significant at a 1\% level. The detailed results of the correlation analysis were presented in Table 5 below.

Table 5: Pearson's correlation

\begin{tabular}{lllllll}
\hline & PE & EE & SI & FC & IN & IB \\
\hline $\mathbf{P E}$ & 1 & & & & \\
\hline $\mathbf{E E}$ & $.614^{* *}$ & 1 & & & \\
\hline $\mathbf{S I}$ & $.402^{* *}$ & $.355^{* *}$ & 1 & & & \\
\hline $\mathbf{F C}$ & $.576^{* *}$ & $.619^{* *}$ & $.315^{* *}$ & 1 & & \\
\hline $\mathbf{I N}$ & $.595^{* *}$ & $.560^{* *}$ & $.422^{* *}$ & $.574^{* *}$ & 1 & \\
\hline $\mathbf{I B}$ & $.222^{* *}$ & $.202^{* *}$ & $.387^{* *}$ & $.212^{* *}$ & $.406^{* *}$ & 1 \\
\hline
\end{tabular}

(Source: Research result)

\subsection{Regression analysis}

Analysis of variances (ANOVA) results showed the regression F-statistics $=132.716 ; \mathrm{df}=4, \mathrm{p}$-value $=0.000$ implying that the model is significant at $5 \%$ confidence level. $\mathrm{R}^{2}$ coefficient was adjusted to 0.475 meant that the linear regression model was built according to the data set at $47.5 \%$. Durbin-Watson statistic was 1.726; thus, there was no autocorrelation among the residuals. 
Table 6: Regression analysis

\section{Coefficients}

\begin{tabular}{|c|c|c|c|c|c|c|c|c|}
\hline & & \multicolumn{2}{|c|}{$\begin{array}{l}\text { Unstandardized } \\
\text { Coefficients }\end{array}$} & \multicolumn{3}{|l|}{$\begin{array}{l}\text { Standardized } \\
\text { Coefficients }\end{array}$} & \multicolumn{2}{|c|}{ Collinearity Statistics } \\
\hline \multicolumn{2}{|c|}{ Model } & $\mathrm{B}$ & Std. Error & Beta & $\mathrm{t}$ & Sig. & Tolerance & VIF \\
\hline \multirow{5}{*}{ IN } & (Constant) & .273 & .156 & & 1.751 & .080 & & \\
\hline & $\overline{\mathrm{PE}}$ & .285 & .043 & .273 & 6.638 & .000 & .533 & 1.876 \\
\hline & $\overline{\text { SI }}$ & .181 & .035 & .170 & 5.129 & .000 & .817 & 1.224 \\
\hline & $\overline{\mathrm{EE}}$ & .185 & .045 & .173 & 4.116 & .000 & .511 & 1.958 \\
\hline & $\mathrm{FC}$ & .284 & .045 & .257 & 6.358 & .000 & .554 & 1.806 \\
\hline
\end{tabular}

According to the results, all independent variables significantly influenced buyers' intention at $5 \%$. VIF coefficients are all below 2, indicating no multicollinearity problem existing in the model. The regression equations to reflect the impacts of four factors on consumers' intention were:

$$
\begin{gathered}
\mathrm{IN}=0.285 \widehat{\mathrm{PE}}+0.181 \widehat{\mathrm{SI}}+0.185 \widehat{\mathrm{EE}}+0.284 \widehat{\mathrm{FC}}(\text { at } 5 \% \text { of a significant level }) \\
\mathrm{IN}=0.273+0.285 \widehat{\mathrm{PE}}+0.181 \widehat{\mathrm{SI}}+0.185 \widehat{\mathrm{EE}}+0.284 \widehat{\mathrm{FC}} \text { (at } 10 \% \text { of a significant level })
\end{gathered}
$$

With the significance of $5 \%$, four factors were influencing the intention of online shopping, the impact level of 6 factors in descending order are (1) Performance expectancy (PE, $\beta=0.273$ ), (2) Facilitating conditions (FC, $\beta=0.257$ ), (3) Effort expectancy (EE, $\beta=0.173$ ) and (4) Social influence (SI, $\beta=0.154$ ). Positive standardized coefficients showed a positive relationship between the explanatory variables and the intention to buy online. Performance expectancy (PE) was assessed as having the most substantial impact on users' intention, while social influence (SI) was the weakest factor.

Estimation of ANOVA in regression F-statistics for the model with IB as the explained variable was 114.700 with p-values equal to 0.000 implied that two models were significant at $5 \%$ of confidence level. $\mathrm{R}^{2}$ for the model was 0.165 meant that the linear regression models were built in accordance with the data set at $16.5 \%$.

Table 7: Regression analysis

\begin{tabular}{|c|c|c|c|c|c|c|c|c|}
\hline \multirow{2}{*}{\multicolumn{2}{|c|}{ Model }} & \multicolumn{2}{|c|}{$\begin{array}{l}\text { Unstandardized } \\
\text { Coefficients }\end{array}$} & \multicolumn{3}{|l|}{$\begin{array}{l}\text { Standardized } \\
\text { Coefficients }\end{array}$} & \multicolumn{2}{|c|}{ Collinearity Statistics } \\
\hline & & $\mathrm{B}$ & Std. Error & Beta & $\mathrm{t}$ & Sig. & Tolerance & VIF \\
\hline \multirow[t]{2}{*}{$\overline{\mathrm{IB}}$} & (Constant) & 1.321 & .168 & & 7.876 & .000 & & \\
\hline & $\overline{\mathrm{IN}}$ & .463 & .043 & .406 & 10.710 & .000 & 1.000 & 1.000 \\
\hline
\end{tabular}

\section{Coefficients}

Based on the regression analysis result, users' intention impacted impulsive buying behavior at $5 \%$ of the significance level. The regression model to present the effect of consumption intention on impulsive buying at $5 \%$ of confidence were: 
$\mathrm{IB}=1.321+0.463 \widehat{\mathrm{IN}}$

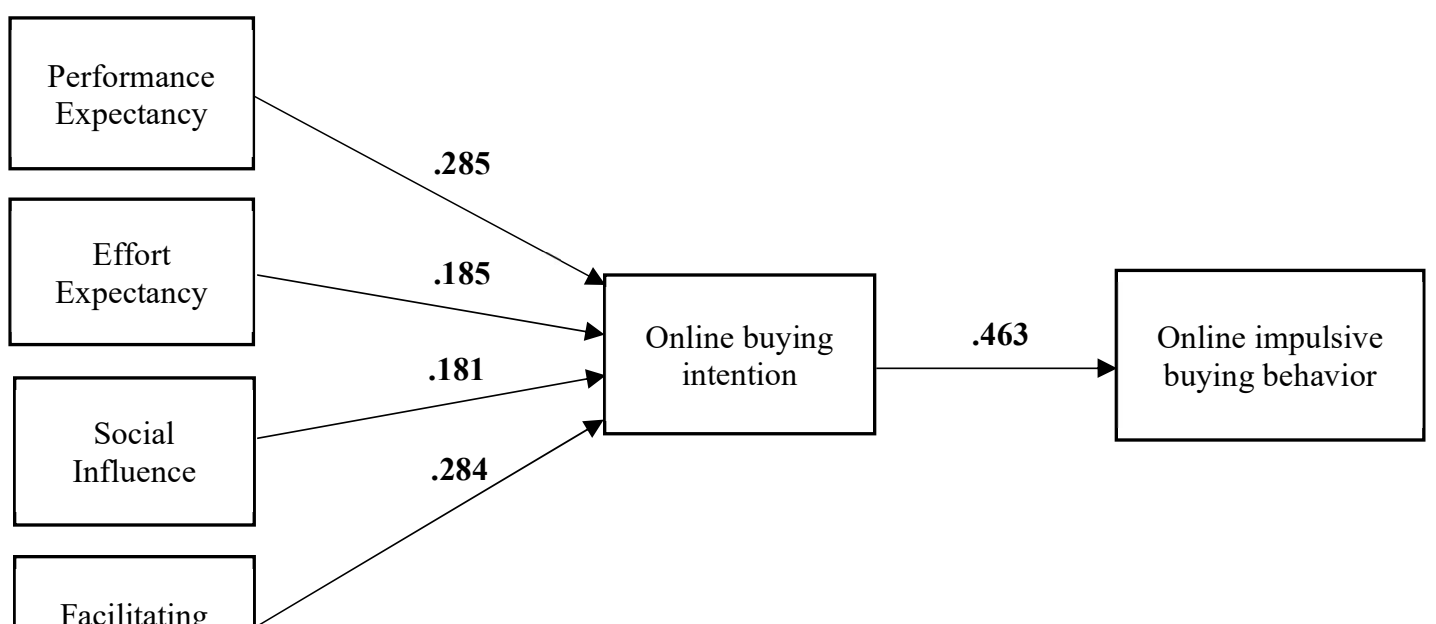

Conditions

Figure 2. Regression analysis

(Source: Research result)

The standardized coefficient was above 0 implied that buyers' intention has a positive impact on impulsive buying. When the users' intention rises by one unit, their impulsive shopping behavior and compulsive buying behavior would likely increase by 0.463 units.

\section{Discussion}

Based on the UTAUT model, this study aims to determine the driving factors of Vietnamese consumers' online impulsive buying behavior. The theoretical framework deployed regards influences of the four independent variables Performance Expectancy (PE), Effort Expectancy (EE), Social Influence (SI), and Facilitating Conditions (FC) to Online Buying Intention (IN) and from that intention to Online Impulsive Buying Behavior (IB). Research results showed that the effect of $\mathrm{PE}, \mathrm{EE}$, and SI factors on the online buying intention was positive and significant, indicating that when the users will have a higher propensity towards purchasing when the shopping platforms' qualities and their normative influences increases, similar to results of Escobar-Rodríguez \& Carvajal-Trujillo (2014) and Zimmerman (2012). However, all hypotheses were supported except H4 concerning the impact of Facilitating conditions on consumers' purchasing intention, implying that the users may not be ready and willing to buy an item despite being equipped with resources, knowledge, or customer services - similar to the result of Celik (2016). Moreover, the research results reveal that online buying intention does bear a positive relationship with online impulsive buying behavior. With these results, the research group hopes to deliver new theoretical contributions to the research topic of online shopping-related behaviors.

\section{Recommendations}

The authors would like to offer the following recommendations for marketers, consumers, and the Government of Vietnam to promote online sales but at the same time, to protect Vietnamese consumers:

Firstly, online shopping sites should improve, upgrade and optimize the service platform (to increase EE), which helps enhance the value of the consumer experience, thereby removing barriers that prevent some from adopting the technology. This measure will directly drive the buyers' intention to continue online purchases while also stimulating their impulsiveness and compulsiveness in shopping behavior. This development, consequently, creating opportunities to boost online shopping sites' revenue and profit. These sites can also increase their attractiveness by building appropriate promotional campaigns to stimulate customers' buying intentions while reaching potential market segments.

Secondly, customers need to acquire knowledge and information from reliable sources such as the Government or reputable organizations to practice safe online buying. This is an incredibly effective way to avoid 
the influences of marketing tricks that would harm their interests. In particular, impulsive buying behavior can also form the foundation for compulsive buying (Moon et al., 2017). Therefore, if there are such behaviors (negative impact on the financial, emotional, and psychological situation), consumers need to correct their behaviors.

Thirdly, policymakers should implement policies that leverage income from developing online businesses to support other sustainable activities in Vietnam. Furthermore, the Government needs to continue supporting SMEs and e-commerce companies with high-quality facilities to participate in more sustainable economic and technology activities. In addition, online shopping platforms must be used to drive consumer behavior in a positive, sustainable, and environmentally friendly way.

\section{Limitations and future research}

Although the analysis results provide both theoretical as well as practical implications for e-commerce related behaviors and marketing-related campaigns, this study has limitations as well as directions for future researchers. The age distribution of the sample is one of the research's limitations. Since about 86 percent of the study was between the ages of 15 and 30, the results might not be valid to buyers above the age of 30 . Thus, it is hoped that further research will overcome this limitation to improve findings of the effect of age on online impulsive purchasing behavior. Moreover, differences in cultural aspects across countries have been found to have a substantial impact on individual expectations and adoptions of online shopping, according to previous studies (Ashraf et al., 2014). The respondents in this study are mainly students and office staff in Hanoi, so future research can be applied in many different regions and cultures to be able to conceptualize and determine if there are cultural differences in terms of these behaviors. In addition, future studies are advocated to study whether this particular behavior leads to a more adverse one, which is known as compulsive buying behavior.

\section{References}

Abushanab, E., \& Pearson, J. M. (2007). Internet banking in Jordan: the unified theory of acceptance and use of technology (UTAUT) perspective. Journal of Systems and Information Technology, 78-97.

Ajzen, I. (1991). The Theory of Planned Behavior. Organizational Behavior and Human Decision Processes, 179211.

Alalwan, A., Dwivedi, Y., \& and Williams, M. (2014). Examining Factors Affecting Customer Intention And Adoption Of Internet Banking In Jordan. UK Academy for Information Systems Conference Proceedings 2014.

Alwahaishi, S., \& Snášel, V. (2013, May). Consumers' Acceptance and Use of Information and Communications Technology: A UTAUT and Flow Based Theoretical Model. Journal of Technology Management and Innovation, 8(2), pp. 61-73.

Ashraf, A., Thongpapanl, N., \& Auh, S. (2014). The application of the technology acceptance model under different cultural contexts: the case of online shopping adoption. Journal of International Marketing, 6893.

Beatty, S.E. and Ferrell, M.E. (1998). Impulse Buying: Modeling Its Precursors. Journal of Retailing, 74, pp. 169191.

Brown, R., Derksen, C., \& Wang, L. (2010). A multi-data set analysis of variability and change in Arctic spring snow cover extent, 1967-2008. Journal of Geophysical Research Atmosphere.

Celik, H. (2016). Customer online shopping anxiety within the Unified Theory of Acceptance and Use Technology (UTAUT) framework. Asia Pacific Journal of Marketing and Logistics, 278-307.

Chan, T. K., Cheung, C. M., \& Lee, Z. W. (2017). The state of online impulse-buying research: A literature analysis. Information \& Management, 204-217 .

Dittmar, H., Long, K., \& Bond, R. (2007). When a Better Self is Only a Button Click Away: Associations Between Materialistic Values, Emotional and Identity-Related Buying Motives, and Compulsive Buying Tendency Online. Journal of Social and Clinical Psychology.

Eastin, M. S. (2002). Diffusion of e-commerce: an analysis of the adoption of four e-commerce activities. Telematics and Informatics, 251-267.

Escobar-Rodríguez, T., \& Carvajal-Trujillo, E. (2014). Online purchasing tickets for low cost carriers: An application of the unified theory of acceptance and use of technology (UTAUT) model. Tourism 
Management, 70-88.

Field, A. (2013). Discovering statistics using IBM SPSS statistics. SAGE Publications.

Flight, R. L., Rountree, M. M., \& Beatty, S. E. (2012). Feeling The Urge: Affect in Impulsive and Compulsive Buying. Journal of Marketing Theory and Practice, 20(4), pp. 453-466.

Gefen, D., Karahanna, E., \& Straub, D. (2003). Trust and TAM in Online Shopping: An Integrated Model. MIS Quarterly, 27(1), 51-90.

Halepete, J., Littrell, M., \& Park, J. (2009). Personalization of Fair Trade Apparel: Consumer Attitudes and Intentions. Clothing and Textiles Research Journal, 143-160.

Hansen, T. (2006). Determinants of consumers' repeat online buying of groceries. The International Review of Retail Distribution and Consumer Research, 16(1), 93-114.

Hung, Y. H., Wang, Y. S., \& Chou, S. C. (2007). User acceptance of e-government services. Kaohsiung: Natl Sun Yat-Sen Univ.

Im, I., Hong, S., \& Kang, M. S. (2011). An international comparison of technology adoption: testing the UTAUT model. Information \& Management, 1-8.

Jin, L., Osman, A., \& Halim, M. (2014). Perceived Usefulness and Trust towards Consumer Behaviors: A Perspective of Consumer Online Shopping. Journal of Asian Scientific Research, 541-546.

Jones, M.A., Reynolds, K.E., Weun, S. and Beatty, S.E. (2003). The Product-Specific Nature of Impulse Buying Tendency. Journal of Business Research, 56, pp. 505-511.

Kang, M.-J., \& Ahn, J.-W. (2011). Impulsive Purchasing in the Digital Era. Journal of the Korean data analysis society, 1631-1642.

Koufaris, M. (2002). Applying the Technology Acceptance Model and Flow Theory to Online Consumer Behavior. Information Systems Research.

Lallmahomed, Rahim, NZA, Ibrahim, R, Rahman, AA. (2013, Aug). Predicting different conceptualizations of system use: Acceptance in hedonic volitional context (Facebook). Computers in Human Behavior, 29(6), p. 2776.

LaRose, R. (2001). On the Negative Effects of E-Commerce: a Sociocognitive Exploration of Unregulated on-line Buying. Journal of Computer-Mediated Communication.

Laumer, S., Eckhardt, A., \& Trunk, N. (2010). Do as your parents say? Analyzing IT adoption influencing factors for full and under age applicants. . Information Systems Frontiers, 169-183.

Le, N. L. (2016). Nghien cuu hanh vi mua sam truc tuyen tren smart phone cua nghuoi tieu dung tai Tp Ho Chi Minh, Truong DH Kinh te Tp Ho Chi Minh. .

Lee, J., Kim, J., \& Moon, J. Y. (2000). What makes Internet users visit cyber stores again? Key design factors for customer loyalty. Proceedings of the SIGCHI Conference on Human Factors in Computing Systems, (pp. 305-312).

Lin, C., \& Anol, B. (2008). Learning online social support: an investigation of network information. CyberPsychology and Behavior, 11(3), pp. 268-272.

Lin, S., \& Lo, L. Y.-S. (2016). Evoking online consumer impulse buying through virtual layout schemes. Behaviour \& Information Technology, 38-56.

Liu, Y., Li, H., \& Hu, F. (2013). Website attributes in urging online impulse purchase: An empirical investigation on consumer perceptions. Decision Support Systems, 829-837.

Moon, M. A., \& Attiq, S. (2018). Psychometric Validation and Prevalence of Compulsive Buying Behavior in an Emerging Economy. Sukkur IBA Journal of Management and Business, 92-113.

Nguyen, T. H., Tran, T. V., Pham, T. T., \& Le, T. T. (2019). Online Shopping Intention and Behavior of Customers: Study of the Extended Unified Theory of Acceptance and Use of Technology, Trust and Long Tail Effect. VNU Journal of Science: Economics and Business, 112-120.

Nunnally, J. C. (1978). Psychometric Theory, $2 d$ ed. New York: McGraw-Hill.

Park, J., Yang, S., \& Lehto, X. (2007). Adoption of mobile technologies for Chinese consumers. Journal of Electronic Commerce Research, 196-206.

Pavlou, P. (2003). Consumer Acceptance of Electronic Commerce: Integrating Trust and Risk with the Technology Acceptance Model. International Journal of Electronic Commerce, pp. 69-103. 
Piron, F. (2001). Defining Impulse Purchasing. Advances in Consumer Research, 509-514.

Riffai, M. M., Grantb, K., \& Edgarc, D. (2012). Big TAM in Oman: exploring the promise of on-line banking, its adoption by customers and the challenges of banking in Oman. International Journal of Information Management, 239-250.

Roberts, J. A., \& Jones, E. (2001). Money Attitudes, Credit Card Use, and Compulsive Buying among American College Students. The Journal of Consumer Affairs, 213-240.

Rook, D. (1987). The buying impulse. Journal of Consumer Research, 14(2), pp. 189-199.

Rook, D. W., \& Fisher, R. J. (1995). Normative Influences on Impulsive Buying Behavior. Journal of Consumer Research, 305-313.

Rook, D. W., \& Gardner, M. P. (1993). In the mood: impulse buying's affective antecedents. Research in consumer behavior, 6(7), pp. 1-28.

Rook, D.W. and Hoch, S.J. (1985). Consuming impulses. Advances in Consumer Research, 12(1), p. 190.

S. Bellini, Maria Grazia Cardinali, B. Grandi. (2017). A structural equation model of impulse buying behavior in grocery retailing. Journal of Retailing and Consumer Services, 36, pp. 164-171.

Sapio, B., Turk, T., Cornacchia, M., Papa, F., Nicolo, E., \& Livi, S. (2010). Building scenarios of digital television adoption: a pilot study. Technology Analysis and Strategic Management, 43-63.

Scherhorn, G., Reisch, L. A., \& Raab, G. (1990). Addictive buying in West Germany: An empirical study. Kaufsucht in Westdeutschland: Eine empirische Studie, 380.

Schor, J. (1998). Time, Labour and Consumption: Guest Editor's Introduction. Time \& Society, 119-127.

Tan, K., Chong, S., \& Lin, B. (2013). Intention to use internet marketing: A comparative study between Malaysians and South Koreans. Kybernetes: The International Journal of Systems \& Cybernetics, 42(8), pp. 888-905.

Tirtiroglu, E., \& Elbeck, M. (2008). Qualifying Purchase Intentions Using Queueing Theory. Journal of Applied Quantitative Methods, 167-178.

Venkatesh, F.D. Davis. (2000, Feb). A Theoretical Extension of the Technology Acceptance Model: Four Longitudinal Field Studies. Management Science, 46(2), pp. 186-204.

Venkatesh, V., Morris, M. G., Davis, G. B., \& Davis, F. D. (2003). User Acceptance of Information Technology: Toward a Unified View. MIS Quarterly, 425-478.

Venkatesh, V., Thong, J. Y., \& Xu, X. (2012). Consumer Acceptance and Use of Information Technology: Extending the Unified Theory of Acceptance and Use of Technology. MIS Quarterly, 157-178.

Venkatesh, V., Thong, J. Y., \& Xu, X. (2012). Consumer Acceptance and Use of Information Technology: Extending the Unified Theory of Acceptance and Use of Technology. MIS Quarterly, 157-178.

Wang, H. W., \& Wang, S. H. (2010). User acceptance of mobile internet based on the unified theory of acceptance and use of technology: investigating the determinants and gender differences. Social Behavior \& Personality: An International Journal, 415-426.

Wells, J. D., Parboteeah, V., \& Valacich, J. S. (2011). Online Impulse Buying: Understanding the Interplay between Consumer Impulsiveness and Website Quality. Journal of the Association for Information Systems.

Williams, M. D., Rana, N., \& Dwivedi, Y. K. (2015). The unified theory of acceptance and use of technology (UTAUT): A literature review. Journal of Enterprise Information Management, 443-488.

Wu, I.-L., Chen, K.-W., \& Chiu, M.-L. (2016, June). Defining key drivers of online impulse purchasing: A perspective of both impulse shoppers and system users. International Journal of Information Management, 36(2), pp. 284-296.

Yang, K. (2010). Determinants of US consumer mobile shopping services adoption: Implications for designing mobile shopping services. Journal of Consumer Marketing, 262-270.

Yu, C. S. (2012). Factors affecting individuals to adopt mobile banking: Empirical evidence from the UTAUT model. Journal of Electronic Commerce Research, 13(2), pp. 104-121.

Zahedi, J. S. (2005). A Theoretical Approach to Web Design in E-Commerce: A Belief Reinforcement Model. Management Science, 1219-1235.

Zhang, J.-X., \& Yang, H.-Y. (2019). Research on the Influencing Factors of Consumers' Purchase Behavior of Pinduoduo E-commerce Platform Based on the UTAUT Model. DEStech Transactions on Economics, Business and Management. 
Zhou, T. (2011). Understanding mobile internet continuance usage from the perspectives of UTAUT and flow. Information Development, 207-218.

Zhou, T., Lu, Y., \& Wang, B. (2010). Integrating TTF and UTAUT to explain mobile banking user adoption. Computers in Human Behavior.

Zimmerman, J. (2012). Using the S-O-R model to understand the impact of website attributes on the online shopping experience. The University of North Texas.

Zwass, V. (1998). Structure And Macro-Level Impacts of Electronic Commerce: FromTechnological Infrastructure to Electronic Marketplaces. Boston: Mass. 